\title{
OBSERVATIONS ON AEROPHYTIC CYANOBACTERIA AND ALGAE FROM TEN CAVES IN THE OJCÓW NATIONAL PARK
}

\author{
Joanna Czerwik-Marcinkowska \\ Department of Botany, Institute of Biology, Jan Kochanowski University \\ Świętokrzyska 15, 25-420 Kielce, Poland \\ e-mail: marcinko@kielce.com.pl
}

Received: 19.04 .2012

\begin{abstract}
This study, carried out in 2010-11, focuses on species composition and distribution of cyanobacterial and algal communities colonizing ten caves (Biała, Ciemna, Koziarnia, Krakowska, Łokietka, Okopy Wielka Dolna, Sąspowska, Sypialnia, Zbójecka and Złodziejska Caves) in the Ojców National Park (South Poland). A total of 85 taxa were identified, 35 of them belonging to cyanobacteria, 30 chlorophytes, and 20 belonging to other groups of algae. Aerophytic cyanobacteria dominated in these calcareous habitats. Nine species, Gloeocapsa alpina, Nostoc commune, Chlorella vulgaris, Dilabifilum arthopyreniae, Klebsormidium flaccidum, Muriella decolor, Neocystis subglobosa, and Orthoseira roseana, were the most abundant taxa in all the caves. The investigated microhabitats offer relatively stable microclimatic conditions and are likely to be responsible for the observed vertical distribution of aerophytic cyanobacteria and algae.
\end{abstract}

Key words: algae, cyanobacteria, caves, Ojców National Park, Poland.

\section{INTRODUCTION}

Caves are unique in terms of specific natural characteristics such as: microclimate, temperature, humidity and others. According to $\mathrm{Mulec}$ and $\mathrm{Kosi}$ (2009), caves have a special place in human history and many caves are inscribed on the United Nations Educational, Scientific and Cultural Organization (UNESCO) World Heritage List. Recently, many caves have experienced intensified tourist visits and to make them more attractive for visitors, artificial illumination was installed which changed physico-chemical conditions in the caves. However, most caves, at least in Europe, are damp and the walls at the entrance are covered with green algal gelatinous mass (P o u ličk ová and
$\mathrm{H}$ a šl e r, 2007). At the entrance of limestone caves and on the surfaces around electrical lights, cyanobacteria compete for light with other algae, bryophytes and ferns, but in the deepest recesses of the caves they are usually the only phototrophs (Round, 1981). Most caves represent stable environments characterized by uniform temperatures throughout the year, high humidity and low natural light (Hernán de z - Mariné and Canals, 1994; Ducarme et al. 2004; P ouličková and Hašler, 2007; Lamprinou et al. 2009). According to La m prin ou et al. (2012), a typical cave is described as having three major habitat zones based on light penetration and intensity: the entrance-, transition-, and dim light zone. Moreover, cave characteristics, such as dimensions, morphology, location, orientation and rocky substrate, can play an important role for the biocommunity structure. All caves belong to habitats of extreme conditions characterized by a low content of nutrients (Pederse n, 2000; M u le c et al. 2008). However, many groups of organisms prefer such conditions for the colonization and growth. The following occur most frequently in caves: liverworts, mosses, some ferns, flowering plants, algae and cyanobacteria (D o b a t, 1970; Kuehn et al. 1992; S anchez et al. 2002; Mulec, 2005; Mulec et al. 2008; Mulec and K o s i, 2009). Algae often play a key role in the food webs and in the colonization processes of rocky habitats (sediments, rocky surfaces, artificial material) as well as they produce colourful effects on the caves walls (Golubi č 1967). These processes are favoured by usually stable environmental conditions prevailing in caves. All these factors make caves attractive for cosmopolitan species, which consequently eliminate the native components (P i p a n , 2005). Although 
infrequently, but new algal species have also been identified in caves (J ones, 1964; Hernandé z- Mariné and Canals, 1994). Aerophytic algae and cyanobacteria are usually observed in cave entrances illuminated by direct or indirect sunlight and also around the artificial light in caves that are open to tourists (Pentecost, 1992; Mulec, 2005; Mulec et al. 2008; Czerwik-Marcinkowska and Mrozińska, 2011).

In Poland algological studies in caves have been carried out by the following researchers: $\mathrm{Star} \mathrm{m} \mathrm{a} \mathrm{h}$ (1963); Mrozińska-Broda and Czerwik- Marcinkowska, (2004); C zerwik-M arcinkowska and Mrozińska, (2008，2009，2010, 2011).

The aim of this study was to present the spatial distribution of aerophytic algae and cyanobacteria growing in ten caves in the Ojców National Park differing in location, morphology and environmental conditions as part of an extensive study of caves in the Polish Jura.

\section{STUDY AREA}

The caves are one of the most characteristic elements of the Ojców National Park and its surroundings. The presence of caves in this area has been noticed for a long time $(\mathrm{Ch}$ arde $\mathrm{z}$ and $\mathrm{Delhez}$, 1981; S zelerewicz and Górny, 1986; B i sek et al. 1992; Gradziński et al. 1995a, b, 1996, 1998, 2007; Gradziński and Szelerewicz, 2004; Górny and Szelerewicz, 2008). These caves were created by underground waters dissolving Jurassic marine limestones ( $\mathrm{M} \mathrm{i} \mathrm{ch}$ a li k and $\mathrm{P}$ a r t y $\mathrm{k} \mathrm{a}, 1992)$. Some of the caves exceed $300 \mathrm{~m}$ in depth. Ten caves: Biała, Ciemna, Koziarnia, Krakowska, Łokietka, Okopy Wielka Dolna, Sąspowska, Sypialnia, Zbójecka and Złodziejska Caves, were studied in the Park (Fig. 1; Table 1). The most attractive caves from the natural and environmental point of view, having corridors longer than $50 \mathrm{~m}$, include the following: Biała, Ciemna, Koziarnia, Krakowska, Łokietka, Okopy Wielka Dolna, Sąspowska and Zbójecka Caves (P a r t y k a , 1997). Only the Łokietka and Ciemna Caves (among the studied ones) are open to tourists.

\section{MATERIALS AND METHODS}

Samples for algological analysis were taken from the ten caves of the Ojców National Park in the spring, summer and autumn of 2010 and 2011. Algal crusts were scraped from the walls and ceiling, using a scalpel, into labelled plastic bags and analysed under a light microscope (Jenamed 2) or inoculated for culturing on agar plates (Figs 4-6). Additionally, in the two caves (Łokietka and Ciemna) open to tourists, samples were also collected from around artificial light sources, at different distances from the source, and from sites of most intensive growth. Scraped material was used directly for observation under the light microscope. Two sampling zones were distinguished in each cave: A - light zone, comprising the entrance (usually lit by sunlight and well-oxygenated); and B - dark zone comprising the chambers illuminated only by weak natural daylight or artificial light.

Collected organisms were cultured on standard Bristol agar medium, at $20^{\circ} \mathrm{C}$ under a $12 / 12 \mathrm{~h}$ light/dark cycle at $3000 \mu \mathrm{Em}^{-2} \mathrm{~s}^{-1}$ provided by $40 \mathrm{~W}$ fluorescent tubes. For transmission electron microscopy (TEM), cells were fixed as previously described (Massalski et al. 1995). Ultra-thin sections were cut with glass knives on a Reichert-Jung ultramicrotome. Observations and photographs were made with a TESLA BS 500 electron microscope. Cells for TEM were double fixed with glutaraldehyde in phosphate buffer and postosmicated with osmium tetroxide in the same buffer, then they were dehydrated in series of alcohols, embedded in the synthetic epoxy resin "SPURR" and polymerized at $70^{\circ} \mathrm{C}$ for $18 \mathrm{~h}$. For scanning electron microscopy (SEM), the samples were treated with $36 \% \mathrm{HCl}$, washed several times with distilled water and boiled in concentrated $\mathrm{H}_{2} \mathrm{O}_{2}$ with $\mathrm{KClO}_{3}$ in order to remove organic matter. Cyanobacteria and algae were identified according to: Anagnostidis and Komárek (1988); Brown and Bold (1964); Brown and Le an (1969); Etll and Gärtner (1988, 1995); Hoffmann (1986, 2002); Ko márek and Anagnostidis $(1986,1989)$; Krammer and Lange - B ertal ot $(1986,1991)$.

\section{RESULTS}

A total of 85 aerophytic algae and cyanobacteria species were identified in the ten caves in the $\mathrm{Oj}$ ców National Park (Fig. 2; Table 2). Overall, cyanobacteria were dominant and represented by 35 species (40\% of the total), green algae 30 species (32.7\%), and 12 diatoms species $(27.2 \%)$. The frequently encountered species among cyanobacteria were as follows: Aphanocapsa parietina Näg., Calothrix fusca (Kutz.) Born. \& Flah., Chroococcus tenax (Kirchn.) Hieronymus and Nostoc commune Vauch. ex Born. \& Flah. They occurred both in the light (A) and dark (B) zones of the studied caves. Microscopic observations revealed that cyanobacteria are arranged in patina assemblages which are blue, brown, green, or gray, and are arranged mosaic-like inside the caves. Among the cyanobacteria present, the following were dominant only in the caves open for tourism, i.e. the Łokietka Cave and the Ciemna Cave: Gloeocapsa alpina (Näg.) 
F. Brand, Nodularia harveyana Thuret ex Born. \& Flah. and Tolypothrix epilithica Näg. The most rare green algae species were: Bracteococcus minor (Chodat) Petrová (Fig. 3), Desmococcus olivaceum (Pers. ex Arch.) Laudon, Muriella decolor Vischer, Scotiellopsis terrestris (Reisigl) Punčochářová \& Kalina and Thelesphaera alpina Pascher. In the Zbójecka and Ciemna Caves, green algae such as: Chlorella vulgaris Beijerinck, Coleochlamys perforata (Lee \& Bold) Ettl \& Gärtn. and Klebsormidium montanum (Skuja) Watanabe, were encountered on well-illuminated surfaces. Diatoms were present in the zone of both direct and diffuse sunlight, but they usually preferred the wet habitats (permanently wet or periodically sprinkled with water dripping and sipping from the ceiling and walls). Among the aerophytic diatoms, the most frequently encountered taxa were: Diadesmis contenta (Grun. in Van Heurck) D.G. Mann in Round, Hantzschia amphioxys (Ehr.) Grunow, Luticola nivalis (Ehr.) D.G. Mann, Orthoseira roseana (Rabenh.) O'Meara, and Pinnularia borealis Ehr. The most species of cyanobacteria and algae (in Biała Cave 11 species, Ciemna Cave - 16, Koziarnia Cave - 9, Krakowska Cave 20, Łokietka Cave - 12, Okopy Wielka Dolna - 18, Sąspowska Cave - 13, Sypialnia Cave - 23, Zbójecka Cave - 25, Złodziejska Cave - 13) were found on the rocky surfaces and in the indentations close to the entrance (the A bright zone). There were also species found only in the places within direct sunlight: Chroococcus cf. ercegovicii Kom. \& Anagn., Chlorogloea novacekii Kom. \& Montejano, Plectonema cf. puteale (Kirchn.) Hansg., Characium strictum A. Braun, Desmococcus olivaceum (Pers. ex Arch.) Laudon and Keriochlamys styria$c a$ Pascher. On the other hand, there were taxa growing only in the close vicinity of electric light: Chlorobotrys simplex Pascher, Klebsormidium montanum (Skuja) Watanabe, Stichococcus allas Reisigl and S. bacillaris Näg. Mosses (e.g. the genus Crotoneuron) or liverworts (the genus Polysiphonia) and ferns (Asplenium trichomonas $\mathrm{L}$. and A. ruta-muraria $\mathrm{L}$.), forming characteristic abundant clusters, were frequently accompanied by aerophytic diatoms and green algae, e.g.: Diadesmis contenta (Grun. in Van Heurck) D.G. Mann in Round, Gomphonema italicum Kütz., Chlorella vulgaris Beijerinck, Trentepohlia aurea (Linné) Martius and Stichococcus bacillaris Näg. In the entrances of the caves open to tourists (Łokietka and Ciemna Caves), cyanobacteria, in particular Calothrix parietina (Näg.) Thuret, Gloeocapsopsis cf. magma (Bréb.) Kom. \& Anagn., Nostoc cf. microscopicum Carm., Phormidium breve (Kütz. ex Gom.) Anagn. \& Kom., and Pseudocapsa dubia Erceg., were competing with other algae (e.g. Chlamydomonas sp., Muriella decolor Vischer, Leptosira terricola Bristol Printz), mosses and ferns for the best illuminated surfaces.

Table 1

Location and basic morphometric characteristics of the ten studied caves (data after Szelerewicz, Górny (1986); Bisek et al. (1992),

Gradziński et al. (1995a, b, 1996, 1998, 2007); Górny, Szelerewicz (2008)

\begin{tabular}{|c|c|c|c|c|c|c|}
\hline Cave & Location & Altitude (m) & Length (m) & Depth (m) & $\begin{array}{l}\text { Orientation of } \\
\text { cave entrance }\end{array}$ & Lithology \\
\hline Biała & Wąwóz Jamki & ca. 398,407 & 84 & 9 & NW & Jurassic limestones \\
\hline Ciemna & Dolina Prądnika & 372 & 209 & 10 & NW, S & Jurassic limestones \\
\hline Koziarnia & Wąwóz Koziarnia & 385 & 90 & 11 & $\mathrm{~W}$ & Jurassic limestones \\
\hline Krakowska & Wąwóz Jamki & 410 & 90 & 11.5 & NW & Jurassic limestones \\
\hline Łokietka & Dolina Sąspowska & 452 & 320 & 7 & NW & Jurassic limestones \\
\hline $\begin{array}{l}\text { Okopy } \\
\text { Wielka Dolna }\end{array}$ & Dolina Prądnika & 380 & 138 & - & $\mathrm{W}$, vertical & Jurassic limestones \\
\hline Sąspowska & Dolina Sąspowska & 370 & 100 & 13 & $\mathrm{E}$ & Jurassic limestones \\
\hline Sypialnia & Wąwóz Stodoliska & 342 & 44 & 1.5 & $\mathrm{~S}$ & Jurassic limestones \\
\hline Zbójecka & Wąwóz Jamki & ca. $370,372,376$ & 189 & 15 & $\mathrm{NW}, \mathrm{W}$, vertical & Jurassic limestones \\
\hline Złodziejska & Wąwóz Jamki & 380 & 45 & 4 & $\mathrm{E}, \mathrm{N}$ & Jurassic limestones \\
\hline
\end{tabular}


Table 2

List of the identified algae and cyanobacteria species from ten caves of the Ojców National Park

\begin{tabular}{|c|c|}
\hline Taxa & Sampling site \\
\hline \multicolumn{2}{|l|}{ Eucaryota } \\
\hline \multicolumn{2}{|l|}{ Chlorophyta } \\
\hline \multicolumn{2}{|l|}{ Chlamydophyceae } \\
\hline Chlamydomonas sp. & $2,4,10$ \\
\hline Tetracystis intermedia (Deason \& Bold) Brown \& Bold & 6 \\
\hline Tetracystis cf. isobilateralis Brown \& Bold & 6 \\
\hline Tetracystis cf. texensis Brown \& Bold & 6 \\
\hline \multicolumn{2}{|l|}{ Chlorophyceae } \\
\hline Bracteacoccus minor (Chodat) Petrová & 4,6 \\
\hline Characium strictum A. Braun & 10 \\
\hline Chlorella vulgaris Beijerinck & $1,4,6$ \\
\hline Chlorococcum nivale Archibald & 1 \\
\hline Chlorosarcina longispinosa Chant. \& Bold & 3 \\
\hline Choricystis minor (Skuja) Fott & 1,9 \\
\hline Coleochlamys perforata (Lee \& Bold) Ettl \& Gärtner & $1,4,6$ \\
\hline Desmococcus olivaceum (Persoon ex Archerson) Laudon & 2,4 \\
\hline Dilabifilum arthopyreniae (Vischer \& Klement)Tschermak-Woess & $6,7,8$ \\
\hline Gloeocystis polydermatica (Kützing) Hindák & $5,6,7$ \\
\hline Interfilum paradoxum Chodat \& Topali & 2 \\
\hline Leptosira terricola (Bristol) Printz & 2 \\
\hline Leptosira sp. & 8,9 \\
\hline Muriella decolor Vischer & $2,4,5,6$ \\
\hline Neocystis subglobosa (Pascher) Hindák & $2,5,6,8$ \\
\hline Podohedra bicaudata Geitler & 8 \\
\hline Scotiellopsis terrestris (Reisigl) Punčochářová \& Kalina & $4,6,8$ \\
\hline Thelesphaera alpina Pascher & 1 \\
\hline \multicolumn{2}{|l|}{ Trebouxiophyceae } \\
\hline Keriochlamys styriaca Pascher & 1 \\
\hline \multicolumn{2}{|l|}{ Klebsormidiophyceae } \\
\hline Klebsormidium flaccidum (Kützing) Silva, Mattox \& Blackwell & $1,6,7,8$ \\
\hline Klebsormidium montanum (Skuja) Watanabe & 2,8 \\
\hline Klebsormidium sp. & 1 \\
\hline Stichococcus allas Reisigl & 8 \\
\hline Stichococcus bacillaris Nägeli & 7,8 \\
\hline Stichococcus sp. & $6,7,8$ \\
\hline \multicolumn{2}{|l|}{ Trentepohliophyceae } \\
\hline Trentepohlia aurea (Linné) Martius & 4,6 \\
\hline \multicolumn{2}{|l|}{ Heterokontophyta } \\
\hline Xanthophyceae & \\
\hline
\end{tabular}


Chlorobotrys simplex Pascher 2

Chlorobotrys terrestris Pascher

Chlorobotrys sp.

$2,3,4,5$

Gloeobotrys piriformis Reisigl

2

Heterococcus caespitosus Vischer

Trachychloron sp.

7,10

Trachychloron simplex Pascher

\section{Eustigmatophyceae}

Eustigmatos sp.

Bacillariophyceae

Aulacoseira sp.

Caloneis silicula (Ehrenberg) Cleve

Diadesmis contenta (Grunow in Van Heurck) D.G. Mann in Round

Gomphonema italicum Kützing

Grunowia tabellaria (Grunow) Rabenhorst

Hantzschia amphioxys (Ehrenberg) Grunow

Luticola sp.

Luticola nivalis (Ehrenberg) D.G. Mann

Nitzschia sp.

Orthoseira roseana (Rabenhorst) O'Meara

Pinnularia borealis Ehrenberg

Pinnularia sp.

Prokaryota

Cyanophyta

Cyanophyceae

Anabaena cf. oscillarioides Bory de Saint-Vincent

Aphanocapsa parietina Nägeli

Calothrix fusca (Kützing) Bornet \& Flahault

Calothrix parietina (Nägeli) Thuret

Calothrix sp.

Chroococcus cf. ercegovicii Komárek \& Anagnost.

Chroococcus tenax (Kirchner) Hieronymus

Chlorogloea novacekii Komárek \& Montejano

Cyanosarcina sp.

$3,4,6,7$

Gloeocapsa alpina (Nägeli) F.Brand

Gloeocapsa biformis Ercegović

Gloeocapsa cf. decorticans (A.Braun) Richter

Gloeocapsa rupicola Kützing

Gloeocapsopsis cf. magma (Bréb.) Kom. \& Anagn.

Gloeothece sp. 


\begin{tabular}{|c|c|}
\hline Microcystis sp. & 8,9 \\
\hline Nodularia harveyana Thuret ex Bornet \& Flahault & 9 \\
\hline Nodularia sp. & $3,4,5,10$ \\
\hline Nostoc commune Vaucher ex Bornet \& Flahault & $1,2,3$ \\
\hline Nostoc cf. microscopicum Carmichael & 6 \\
\hline Nostoc punctiforme (Kützing ex Hariot) Hariot & 8,9 \\
\hline Nostoc sphaericum Kützing & 1,10 \\
\hline Nostoc sp. & 5,9 \\
\hline Phormidium amoenum Kütz. ex Gom. \& Komárek & 7 \\
\hline Phormidium breve (Kütz. ex Gom.) Anagn. \& Komárek & $6,7,8,9$ \\
\hline Phormidium sp. & 2,9 \\
\hline Plectonema cf. puteale (Kirchner) Hansgirg & 2 \\
\hline Pseudocapsa dubia Ercegović & 1,2 \\
\hline Schizotrix sp. & 2 \\
\hline Synechococcus elongatus Nägeli & 3,4 \\
\hline Tolypothrix epilithica Nägeli & $5,7,9$ \\
\hline Tolypothrix tenuis Kützing ex Bornet \& Flahault & 6 \\
\hline Tolypothrix sp. & 2,8 \\
\hline
\end{tabular}

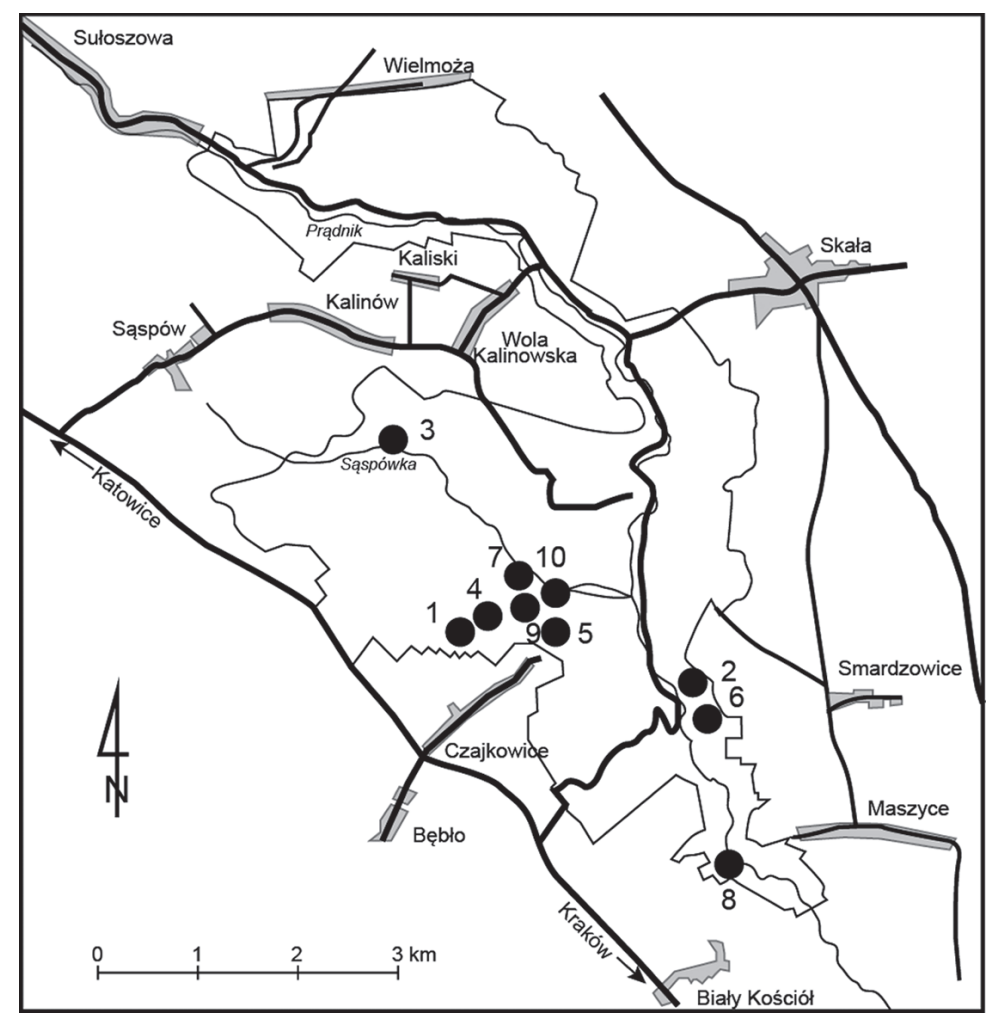

Fig. 1. Location of studied caves in the Ojców National Park (1 - Biała Cave; 2 - Ciemna Cave; 3 - Koziarnia Cave; 4 - Krakowska Cave; 5 - Łokietka Cave; 6 - Okopy Wielka Dolna Cave; 7 - Sąspowska Cave; 8 - Sypialnia Cave; 9 - Zbójecka Cave; 10 - Złodziejska Cave). 


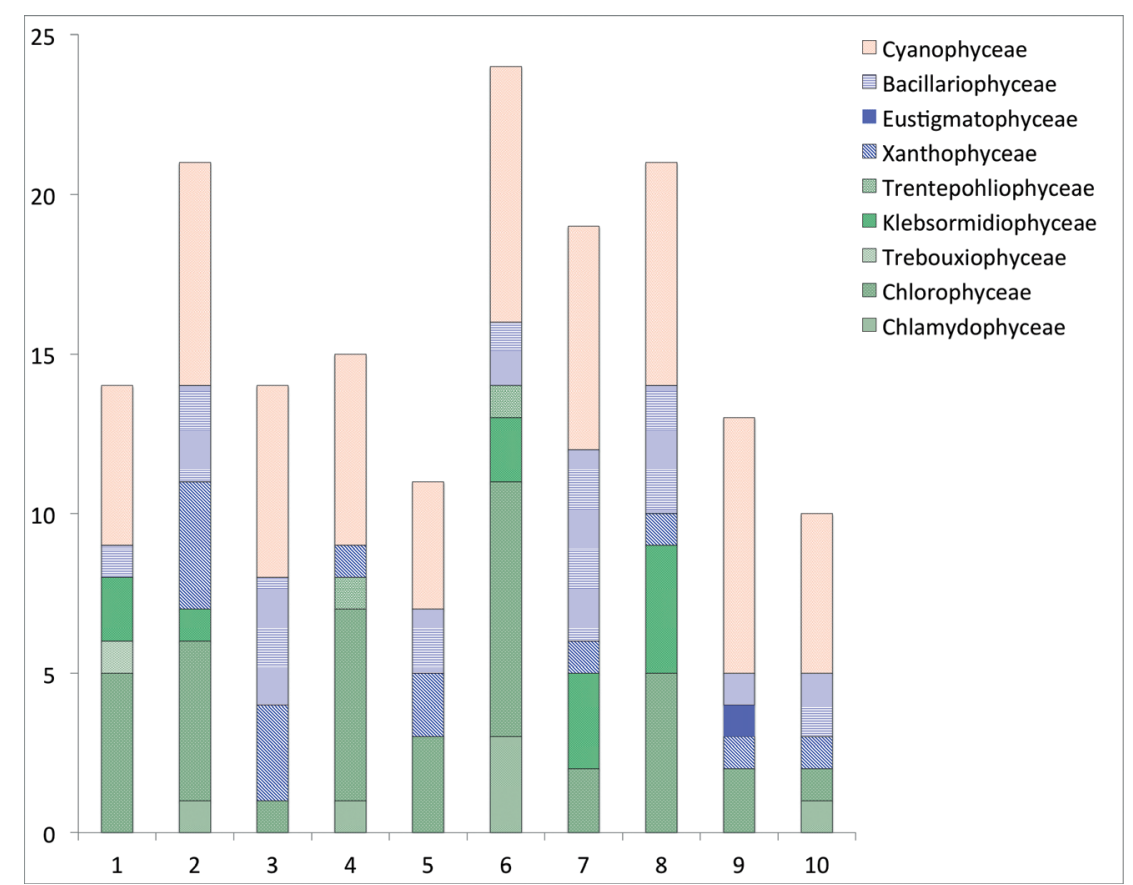

Fig. 2. Participation of particular groups of algae and cyanobacteria in ten studied caves.
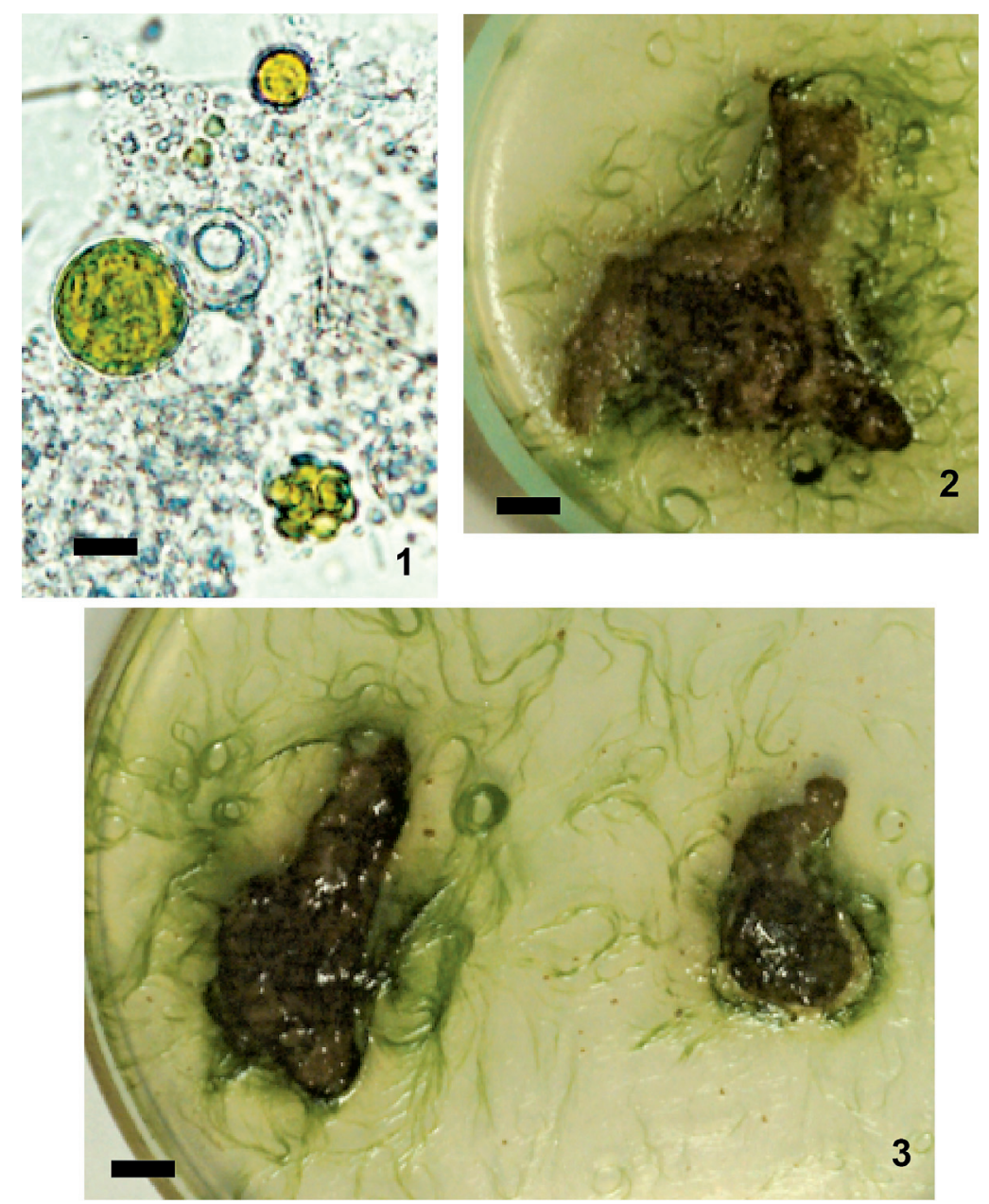

Fig. 3. Bracteacoccus minor (Chodat) Petrová. 1- macroscopic view of young cells; $2-3$ - algological materials on agar plates in lab. Light micrographs [scale bar: $10 \mu \mathrm{m}$ ]. 

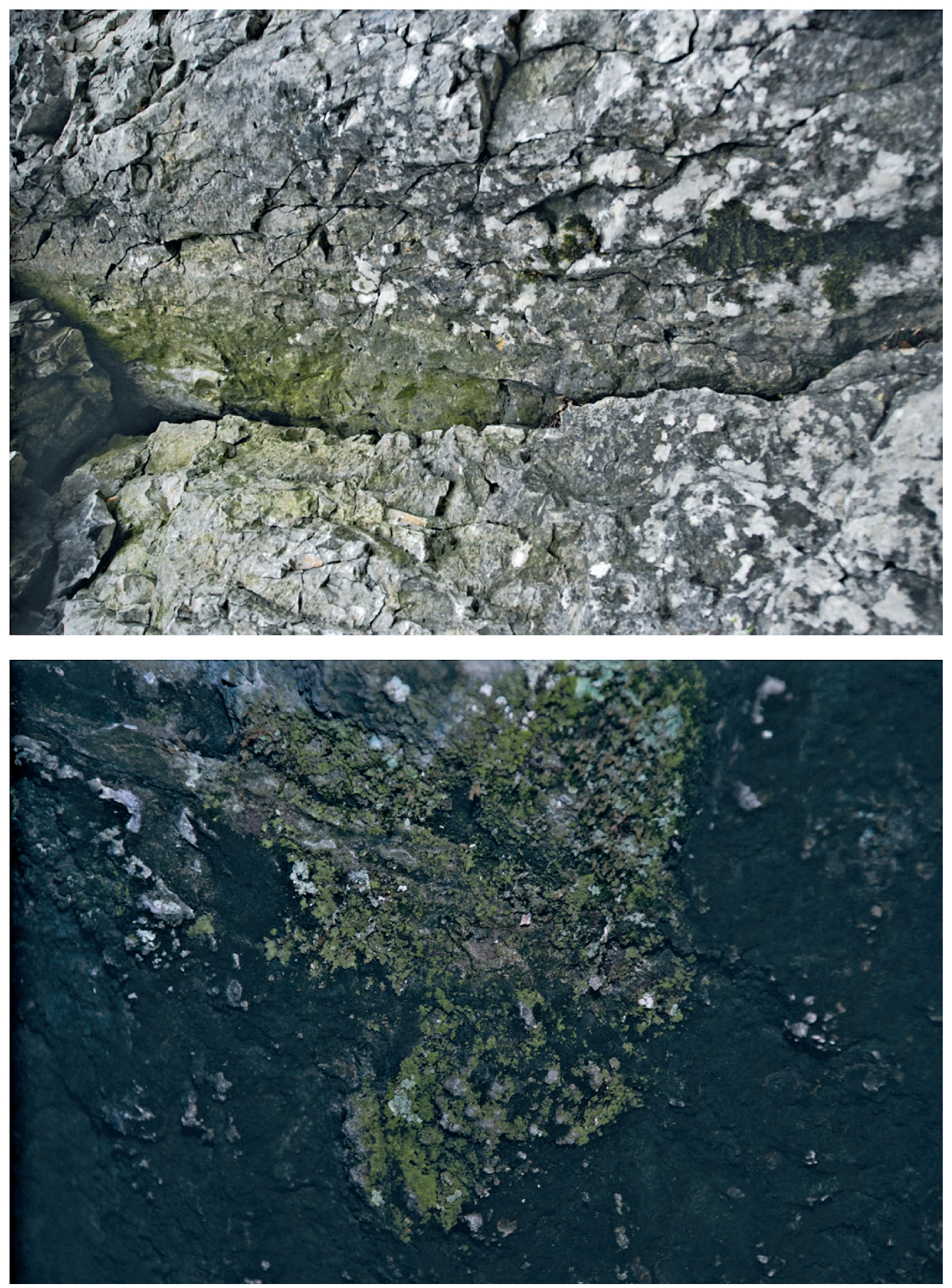

Fig. 4. Epilithic algae and cyanobacteria and their subaeric habitats (Łokietka Cave). 

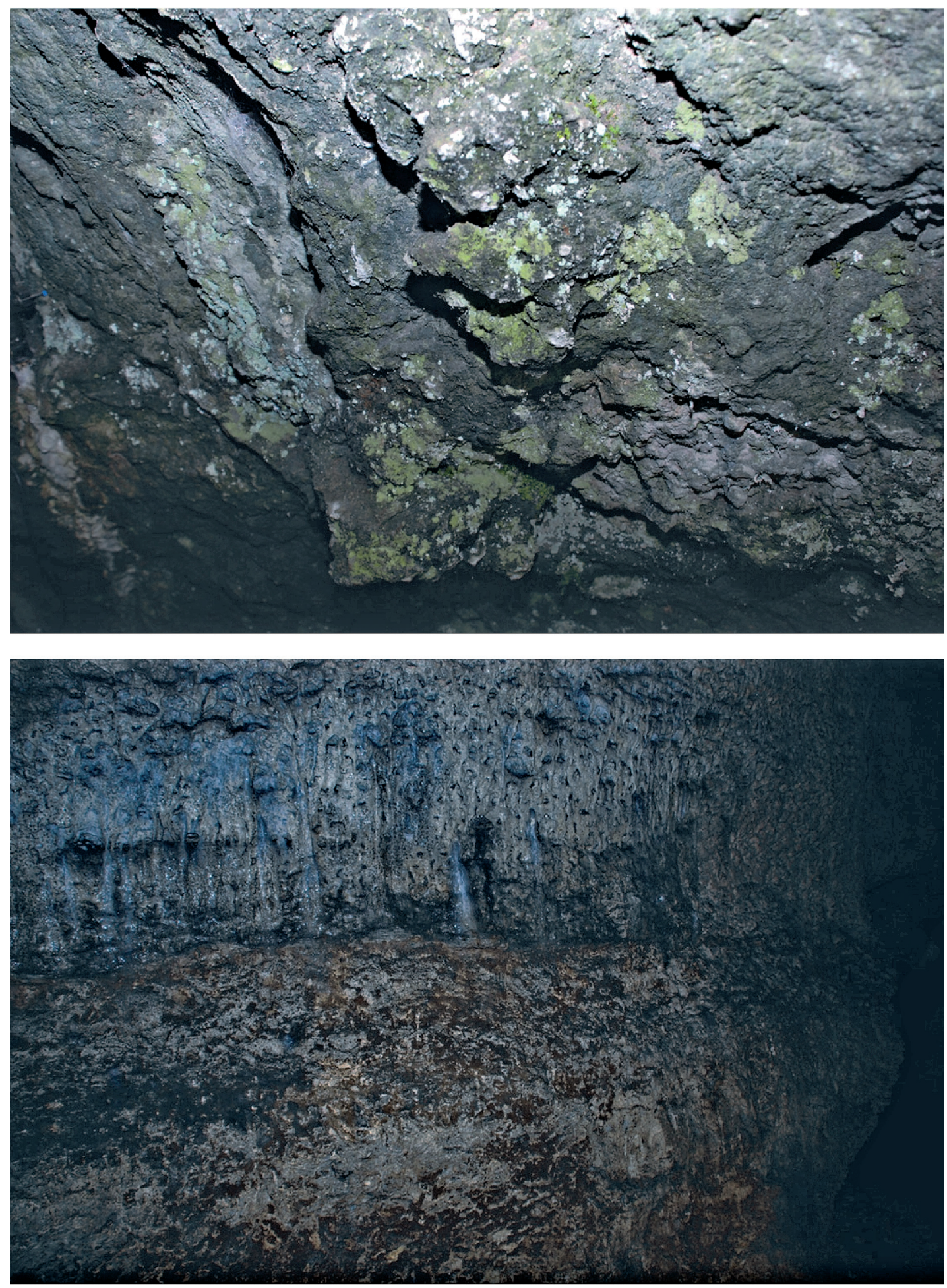

Fig. 5. Aerophytic cyanobacteria and algae in different microhabitat zones in Ciemna Cave. 


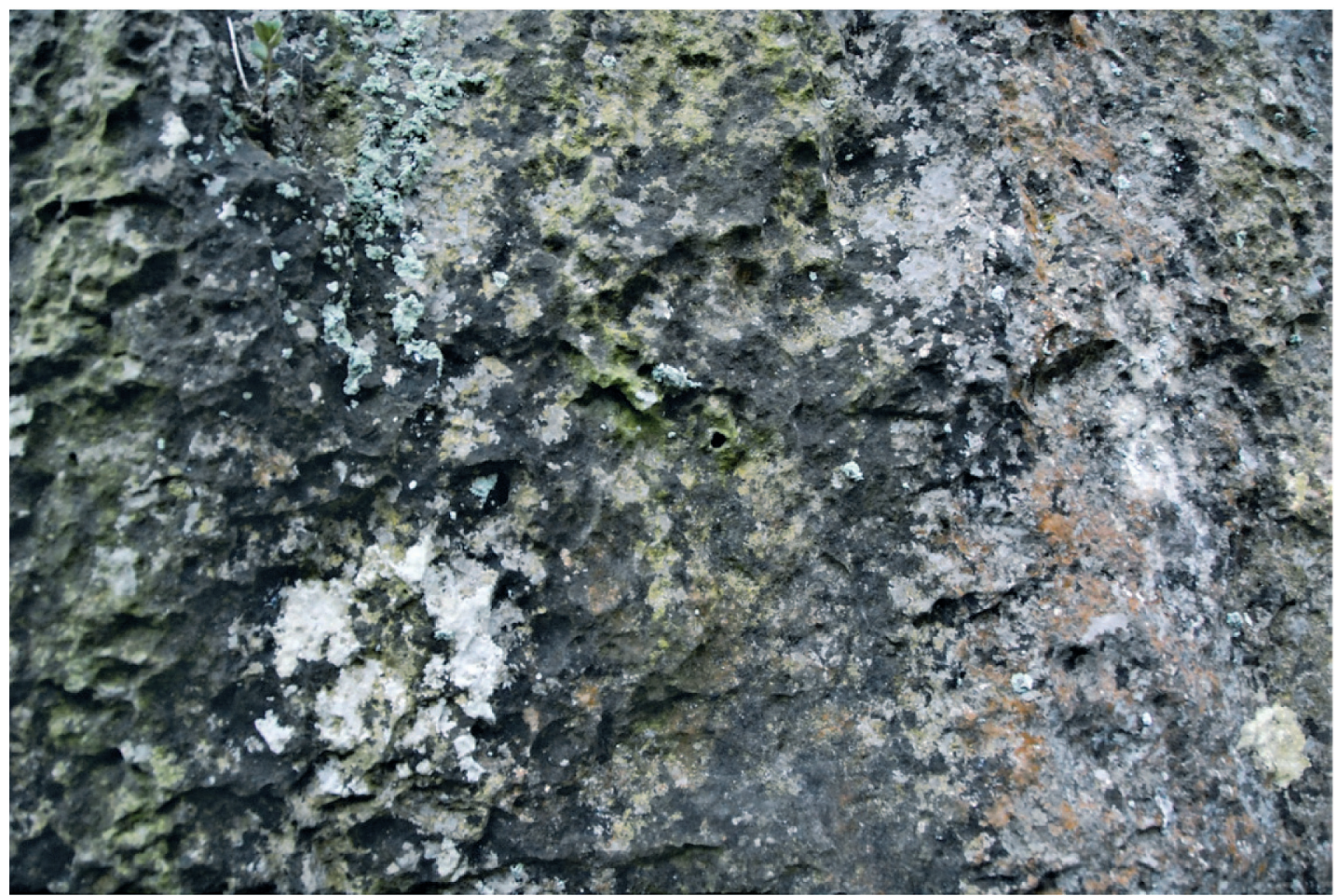

Fig. 6. The wall of Ciemna Cave cover with growths of aerophytic cyanobacteria and algae, liverworts and mosses.

\section{DISCUSSION}

Cyanobacteria prevail in cave entrances compared to other algal groups $(\mathrm{Mulec} 2005 ; \mathrm{Mu}$ le c and Kosi, 2008). They colonize various parts of cave entrances where biodiversity of organisms is the lowest (Vinogradova et al. 1998). Water relations in caves are as important for cyanobacteria and algae growth and colonization (P e n t e c o s t and W hit to n, 2000). According to L a m prin o u et al. (2009), cave aerophytic assemblages are dominated by cyanobacteria, which represent the first photosynthetic colonizers on the calcareous surfaces usually thriving both as epiliths and endoliths. Epilithic assemblages form extensive dark-green coverings (with Phormidium breve as the dominant species) or pale blue-green to whitish coverings (with Tolypothrix epilithica as the dominant species). Cyanobacteria, green algae and diatoms constituted an essential component of the flora of the studied caves.

R o und (1981) differentiated the distribution of phototrophes depending on the access of either natural or artificial light. The development of algae visible in the form of green cover of cave walls is undoubtedly connected with the availability of light and specific microclimate. The microclimate in caves is influenced by air circulation, hydrological conditions, and isolation of a cave from outside thermal influences (Martinez and Asencio, 2010). Also the presence of tourists usually results in an increase of other- wise constant temperature, with the manner in which algae hibernate. Green algae, which dominate the flora of caves, hibernate in the form of different resting cells (cysts and spores). It was observed that in the studied ten caves of the Ojców National Park green algae and diatoms increased their quantity at a higher level of humidity. According to A s e n c i o and A b o al (2000) as well as Pouličková and $\mathrm{Hašler} \mathrm{(2007),} \mathrm{the}$ majority of caves in Europe are characterized by average humidity (ca. 70\%) and their entrance walls are just covered by green algae and cyanobacteria.

In the Eokietka and Ciemna Caves open for tourism, separate chambers with artificial lighting create habitats in which the species composition of cyanobacteria and algae was very similar. According to $\mathrm{R}$ o u n d (1981), P e n te c o s t, (1992) as well as Pentec o s t and $\mathrm{Zh} \mathrm{ang} \mathrm{(2001),} \mathrm{the} \mathrm{type} \mathrm{of} \mathrm{substratum} \mathrm{is} \mathrm{an} \mathrm{im-}$ portant factor determining the species composition, distribution and structure of algal communities. It was observed likewise that cyanobacteria such as: Anabena cf. oscillarioides Bory de Saint-Vin., Gloeocapsa biformis Erceg., Nostoc punctiforme (Kütz. ex Hariot) Hariot, and some aerophytic diatoms (Caloneis silicula (Ehr.) Cl., Grunowia tabellaria (Grun.) Rabenh. and Hantzschia amphioxys (Ehr.) Grun.) were dependant on temperature, light and humidity. These cyanobacteria and algae prefer humid places during their development, but they also display considerable resistance to drying as well as to low air temperature during winter. The adaptation mechanism of algae living in 
low temperature is not yet precisely known $(\mathrm{M} \mathrm{u} \mathrm{le} \mathrm{c}$ and $\mathrm{K}$ o s i , 2008, 2009). It can be therefore concluded that the environmental conditions in the ten caves of the Ojców National Park are stable and conducive to consequent development of cyanobacteria, green algae and aerophytic diatoms.

Protection of aerophytic cyanobacteria and algae in the caves, particularly those open to tourists (i.e. Łokietka Cave, Ciemna Cave), requires full recognition of existing and potential threats regarding the geological structure of the caves. Monitoring of the caves would enable the direction of the most important threats to be documented (e.g. the development of algae on different forms of dripstone formations, including flowstones, stalagmites and small stalactites). Species protection in the caves should be directed towards identification of rare, native, endemic and threatened species (U rb an, 2006; P onikiewic z, 2008).

\section{Acknowledgements}

The author is very grateful to Dr hab. Michat Gradziński for his helpful discussions on the manuscript, Dr hab. Andrzej Massalski for his advice and critical comments, and the anonymous reviewers for valuable remarks on the manuscript. The study was funded by the National Science Center grant No. N N304 275640.

\section{REFERENCES}

Anagnostidis K., Komárek J. 1988. Modern approach to the classification system of Cyanophytes, 3-Oscillatoriales. Archiv. Hydrobiol. Suppl. 80, Algol. Studies 50-53: 327-472.

Asencio A.D., Aboal M. 2000. Algae from La Serreta cave (Murcia, SE Spain) and their environmental conditions. Algol. Studies 96: 59-78.

Bisek K., Gradziński M., Wawryka M. 1992. Jaskinie Ojcowskiego Parku Narodowego, Wąwóz Koziarnia. Ojcowski Park Narodowy, Muzeum im. Prof. Władysława Szafera, Ojców, 1-52. (in Polish)

B row n R.M. Jr., B old H.C. 1964. Comparative studies of the algal genera Tetracystis and Chlorococcum. Phycol. Studies V. Univ. Texas Publ. 6417: 1-213.

Brown R.M. Jr., Lean J.R. 1969. New taxonomic criteria in classification of Chlorococcum species, II. Pyrenoid fine structure, J. Phycol. 5: 114-118.

Chardez D., Delhez F. 1981. Przyczynek do znajomości mikroorganizmów jaskiń Polski / Microorganisms of Polish caves. Rocz. Muz. Częst. Przyr. 5: 9-13 (in Polish)

Czerwik-Marcinkowska J., Mrozińska T. 2008. Glony i sinice wybranych jaskiń Ojcowskiego Parku Narodowego. Materiały konferencji naukowej Pieskowa Skała, 12-14 czerwca 2008 r. Streszczenia referatów i przewodnik sesji terenowych, 54. (in Polish)
Czerwik-Marcinkowska J., Mrozińska T. 2009. Epilithic algae from caves of the Krakowsko-Częstochowska Upland (Southern Poland). Acta Soc. Bot. Pol., 78, 4: 301-309.

Czerwik-Marcinkowska J., Mrozińska T. 2010. Ochrona różnorodności biologicznej ekstremalnych siedlisk jaskiniowych Ojcowskiego Parku Narodowego. Streszczenia referatów i przewodnik sesji terenowych. Materiały konferencji naukowej Ojców, 17-19 czerwca 2010, 35. (in Polish)

Czerwik-Marcinkowska J., Mrozińska T. 2011. Algae and cyanobacteria in caves of the Polish Jura. Polish Bot. J., 56(2): 203-243.

D obat K. 1970. Considérations sur la vegetation cryptogamique des grottes du Jura Souabe (sud-ouest de l'Allemagne). Annales de Spéléologie, 25, 4: 872-907.

Ducarme X., André H.M., Wauthy G., Lebrun Ph. 2004. Comparison of endogeic and cave communities: microarthropod density and mite species richness. Eur. J. Soil. Biol. 40: 129-138.

Ettl H., Gärtner G. 1988. Tetrasporales, Chlorococcales, Gloeodendrales, Chlorophyta, II. [In:] Ettl H., Gerloff J., Heynig H., Fischer G. (eds.), Süswasserflora von Mitteleuropa. Verlag, Stuttgart, New York, 1-453.

Ettl H., Gärtner G. 1995. Syllabus der Boden- Luft und Flechtenalgen. Fischer G., Verlag. Stuttgart, Jena, New York, 1-720. (in German)

Golubič S. 1967. Algenvegetation der Felsen. [In:] Elster H., J., Ohle W. (eds.), Die Biennengewässer: E. Schweitzerbart'sche Verlagsbuchhandlung. Stuttgart, 23-183. (in German)

Górny A., Szelerewicz M. 2008. Jaskinia Szachownica od nowa. / Szachownica Cave again. Jaskinie (The Caves), 53: 30-32. (in Polish)

Gradziński M., Górny A., Szelerewicz M. 1995a. Jaskinie Ojcowskiego Parku Narodowego, Wąwóz Jamki. Ojcowski Park Narodowy, Muzeum im. Prof. Władysława Szafera, Ojców, 1-92. (in Polish)

Gradziński M., Wawryka M., Bisek K., Michalska B. 1995b. Jaskinie Ojcowskiego Parku Narodowego, Dolina Sąspowska, Część Zachodnia. Ojcowski Park Narodowy, Muzeum im. Prof. Władysława Szafera, Ojców, 1-60. (in Polish)

Gradziński M., Michalska B., Wawryka M., B i s e k K. 1996. Jaskinie Ojcowskiego Parku Narodowego, Chełmowa Góra. Ojcowski Park Narodowy, Muzeum im. Prof. Władysława Szafera, Ojców, 1-70. (in Polish)

Gradziński M., Michalska B., Szelerewicz M., Wawryka M. 1998. Jaskinie Ojcowskiego Parku Narodowego, Dolina Prądnika, Część Południowo-Zachodnia. Ojcowski Park Narodowy, Muzeum im. Prof. Władysława Szafera, Ojców, 1-54.

Gradziński M., Michalska B., Wawryka M., Szelerewicz M. 2007. Jaskinie Ojcowskiego Parku Narodowego, Dolina Prądnika, Góra Koronna, Góra Okopy. Ojców, Ojcowski Park Narodowy, Muzeum im. Prof. Władysława Szafera, 1-122. (in Polish) 
Gradziński M., Szelerewicz M. 2004. Jaskinie Wyżyny Krakowsko-Wieluńskiej - liczba i rozmieszczenie. [In:] J. Partyka (Ed.), Zróżnicowanie i przemiany środowiska przyrodniczo-kulturowego Wyżyny Krakowsko-Częstochowskiej. Tom 1. Przyroda. Ojcowski Park Narodowy, Ojców, 69-82. (in Polish)

Hernández-Mariné M., Canals T. 1994. Herpyzonema pulverulentum (Mastigocladaceae), a new cavernicolous atmophytic and limeincrusted cyanophyte. Archiv für Hydrobiol./Algol. St., 75: 123-136.

Hoffma n n L. 1986. Cyanophycées aériennes et subaériennes du Grand-Duché de Luxembourg. Bulletin du Jardin Bot. Nat. de Belgique, 56: 77-127.

Hoffmann L. 2002. Caves and other low-light environments: aerophytic photoautotrophic microorganisms. [In:] Bitton G. (Ed.), Encyclopedia of Environmental Microbiology, New York, John Wiley \& Sons, 835843.

Jones H.J. 1964. Algological investigations in Mammoth cave, Kentucky. Int. J. of Speleol., 1(4): 491-516.

Komárek J., Anagnostidis K. 1986. Modern approach to the classification system o Cyanophytes 2 - Chroococcales, Arch. Hydrobiol. Suppl. 73, Algol. Studies. 43: 157-226.

Komárek J., Anagnostidis K. 1989. Modern approach to the classification system of Cyanophytes 4 - Nostocales. Arch. Hydrobiol. Suppl. 82, 3, Algol. Studies. 56: $247-345$.

Krammer K., Lange-Bertal ot H. 1986. Bacillariophyceae 1.Teil: Naviculaceae. [In:] H. Ettl, J. Gerloff, H. Heynig, D. Mollenhauer, G. Fischer (eds.), Süsswasserflora von Mitteleuropa 2/1. Verlag Stuttgart, New York, 1-654.

Krammer K., Lange-Bertal ot H. 1991. Bacillariophyceae 3. Teil: Centrales, Fragilariaceae, Eunotiaceae. [In:] H. Ettl, J. Gerloff, H. Heynig, D. Mollenhauer, G. Fischer (eds.), Süsswasserflora von Mitteleuropa 2/3. Verlag. Stuttgart, Jena. 1-456.

Kuehn K.A., Oneil R.M., Koehn R.D. 1992. Viable photosynthetic microalgal isolates from aphotic environments of the Edwards aquifer (central Texas). Stygologia, 7(3): 129-142.

Lamprinou V., Pantazidou A., Papadogiannaki G., Radea C., Economou-Amilli A. 2009. Cyanobacteria and associated invertebrates in Leontari Cave, Attica (Greece). Fottea 9(1): 155-164.

Lamprinou V., Danielidis D.B., EconomouAmilli A., Pantazidou A. 2012. Distribution survey of Cyanobacteria in three Greek caves of Peloponnese. Inter. Jour. of Spel., 41(2): 267-272.

Mart nez A., Asencio A.D. 2010. Distribution of cyanobacteria at the Gelda Cave (Spain) by physical parameters. J. of C. K. Studies, 72: 11-20. DOI: 10.4311/ jcks20091sc0082.

Massalski A., Mrozińska T., Olech M. 1995. Lobococcus irregularis (Boye-Pet.) Reisigl var. nov. (Chlorellales, Chlorophyta) from King George Island,
South Shetland Islands, Antarctica, and its ultrastructure. Nova Hedwigia 61: 199-206.

Michalik S., Partyka J. 1992. Scientific-didactic Trail „Chełmowa Mountain“. Ojców National Park. KAW, Kraków, 1-74.

Mrozińska-Broda T., Czerwik-Marcinkowska J. 2004. Eukariotic (epilithic) algae found in caves in the Kraków-Częstochowa Upland. [In:] Partka J. (ed.), The diversification and transformation of natural and cultural environment of the Kraków-Częstochowa Upland. OPN, Ojców. 1: 171-178.

Mulec J. 2005. Algae in the karst caves of Slovenia [Ph.D. thesis], Ljubljana, University of Lubljana, 1-149.

Mulec J., Gorazd K., Vrhovšek D. 2008. Characterization of cave aerophytic algal communities and effects of irradiance levels on production of pigment. J. C. K. Studies. 70, 1: 3-12.

Mulec J., Kosi G. 2008. Algae In the aerophytic habitat of Račiške ponikve cave (Slovenia). Natura Sloveniae 10(1): 39-49.

Mulec J., Kosi G. 2009. Lampenflora alga and methods of growth control. J. C. K. Studies. 71, 2: 109-115.

Partyka J. 1997. Ojcowski Park Narodowy przewodnik turystyczny (The Ojców National Park tourist guide). Wyd. Muza, 1-87. (in Polish)

Ponikiewicz A. 2008. Problems of protection natural environmental in Polish caves. Materiały konferencji naukowej, Ekologiczne problemy XXI wieku. UW, 15-21.

Pouličková A., Hašler P. 2007. Aerophytic diatoms from caves in central Moravia (Czech Republic), Preslia 79: 185-204.

Pedersen K. 2000. Exploration of deep intraterrestrial microbial life: current perspective. MiniReview: FEMS Microbiology Letters. 185: 9-16.

Pentecost A. 1992. A note on the colonisation of limestone rocks by cyanobacteria. Arch. Hydrobiol., 124: 167-172.

Pentecost A., Whitton B.A. 2000. Cyanobacterial mats and stromatolites. [In:] Whitton B.A., Potts M., (eds.) The ecology of Cyanobacteria II. Their diversity in time and space. Kluwer Acad. Publish., 88-262. DOI: $10.1007 / 978-94-007-3855-3$

Pentecost A., Zhang Z. 2001. The distribution of plants in Scoska Cave, North Yorkshire, and their relationship to light intensity. Int. J. Speleol. 30: 27-37. DOI: $10.5038 / 1827-806 X .30 .1 .3$

Pipan T. 2005. Epikarst- a promising habitat: copepod fauna, its divinity and ecology: a case study from Slovenia (Europe). ZRC Publishing, Ljubljana, 1-101.

Round F.E. 1981. The ecology of algae. Cambridge University Press, Cambridge, London, New York, New Rochelle, Melbourne, Sydney, 1-653.

Sanchez M., Alcocer J., Escobar E., Lugo A. 2002. Phytoplankton of cenotes and anchialine caves along a distance gradient from the northeastern coast of Quintana Roo, Yucatan Peninsula. Hydrobiol. 467 (1-3): 79-89. 
St a r m a ch K. 1963. New species of the order Dinococcales (Pyrrhophyta) from the Twardowski Cave in Kraków. Acta Hydrobiol. 5(4): 337-342.

Szelerewicz M., Górny A. 1986. Jaskinie Wyżyny Krakowsko-Wieluńskiej. PTTK Kraj, Kraków, 1-200. (in Polish)

Urba n J. 2006. Prawna i praktyczna ochrona jaskiń w Polsce. / Legal and practical protection of caves in Poland. Chr. Przyr. Oj. 1(62): 53-72. (in Polish)

Vinogradova O.N., Kovalenko O.V., Wasser S.P., Nevo E., Weinstein-Evron M. 1998. Species diversity gradient to darkness stress in blue-green algae/cyanobacteria: a microscale test in a prehistoric cave, Mount Carmel, Israel. Isr. J. Plant Sci. 46: 229-238.

\section{Obserwacje aerofitycznych sinic i glonów w dziesięciu jaskiniach Ojcowskiego Parku Narodowego}

\section{Streszczenie}

Badania algologiczne, przeprowadzone wiosną, latem i jesienią 2010 i 2011 roku wykazały różnorodność występowania sinic i glonów w dziesięciu jaskiniach Ojcowskiego Parku Narodowego (Jaskinia Biała, Ciemna, Koziarnia, Krakowska, Łokietka, Okopy Wielka Dolna, Sąspowska, Sypialnia, Zbójecka and Złodziejska). Zidentyfikowano łącznie 85 gatunków aerofitycznych glonów i sinic, w tym 35 taksonów reprezentujących sinice, 30 gatunków zielenic i 20 przedstawicieli pozostałych grup taksonomicznych badanej algoflory. Niewątpliwie aerofityczne sinice dominują na wapiennych mikrosiedliskach jaskiniowych. Dziewięć gatunków glonów i sinic, spośród występujących w jaskiniach, spotykano najliczniej, były to: Gloeocapsa alpina, Nostoc commune, Chlorella vulgaris, Dilabifilum arthopyreniae, Klebsormidium flaccidum, Muriella decolor, Neocystis subglobosa, Orthoseira roseana. Badane mikrosiedliska jaskiniowe wykształcają stosunkowo stabilne warunki mikroklimatyczne, będące odpowiedzią na rozmieszczenie i występowanie aerofitycznych glonów i sinic. 
